\title{
Comparing written Indian Englishes with the new Corpus of Regional Indian Newspaper Englishes (CORINNE)
}

\author{
Asya Yurchenko, Sven Leuckert and Claudia Lange \\ Technische Universität Dresden
}

\section{Abstract}

This article introduces the new Corpus of Regional Indian Newspaper Englishes (CORINNE). The current version of CORINNE contains news and other text types from regional Indian newspapers published between 2015 and 2020, covering 13 states and regions so far. The corpus complements previous corpora, such as the Indian component of the International Corpus of English (ICE) as well as the Indian section of the South Asian Varieties of English (SAVE) corpus, by giving researchers the opportunity to analyse and compare regional (written) Englishes in India.

In the first sections of the paper we discuss the rationale for creating CORINNE as well as the development of the corpus. We stress the potential of CORINNE and go into detail about selection criteria for the inclusion of newspapers as well as corpus compilation and the current word count. In order to show the potential of the corpus, the paper presents a case study of 'intrusive as', a syntactic feature that has made its way into formal registers of Indian English. Based on two subcorpora covering newspapers from Tamil Nadu and Uttarakhand, we compare frequencies and usage patterns of call (as) and term (as). The case study lends further weight to the hypothesis that the presence or absence of a quotative in the majority language spoken in an Indian state has an impact on the frequency of 'intrusive as'. Finally, we foreshadow the next steps in the development of CORINNE as well as potential studies that can be carried out using the corpus.

\section{Introduction}

After several decades of research on Indian English (IndE) it remains one of the most intriguing varieties of English. It presents unique challenges and opportunities to linguists and the world Englishes paradigm, not least due to the enor- 
mous size of India and the linguistic diversity that comes with it. One of the biggest question marks until today concerns the status of the variety in Schneider's (2003, 2007) 'Dynamic Model of Postcolonial Englishes' and the more recent 'Extra- and Intraterritorial Forces' (EIF) model conceptualised by Buschfeld and Kautzsch (2017). A pressing issue in this regard - and one of the likely reasons for its unclear status - concerns the fact that IndE is not, as the name implies, a monolithic variety. Rather, as Sridhar (2020: 253) suggests: "In empirical terms, it would be more accurate to refer to Indian Englishes". Labade et al. (2020) show that living in a rural or urban area as well as the linked aspect of (access to) education play an important role in how Indians in Maharashtra view English, Hindi, Marathi, and other regional languages, and also how often and in which contexts they use them. This means that, in the state of Maharashtra alone, acquisitional contexts, attitudes towards English and other languages, and proficiency levels differ. In addition, many different languages are consistently in contact in India, both intra- and inter-individually. Accordingly, the term 'Indian English' can legitimately only be understood as an umbrella term for a broad set of sometimes vastly different varieties.

In this paper, we introduce the new Corpus of Regional Indian Newspaper Englishes (CORINNE) with a description of its development as well as a case study. This corpus is currently still in development but already contains roughly 20 million words from different regional newspapers published in various states of India. CORINNE complements previous corpora such as the Indian component of the International Corpus of English (ICE) as well as the Indian subsection of the South Asian Varieties of English (SAVE) corpus but offers the hitherto novel opportunity of comparing regional Indian Englishes with each other.

In Section 2, we explain our rationale for creating CORINNE. Section 3 introduces CORINNE with a retrospective on ICE and SAVE as well as information on selection criteria for newspapers, corpus compilation, and word count. Next, Section 4 presents the background to our case study of the 'intrusive as' construction. Previous studies by Koch et al. (2016) and Lange (2016) have shown that this construction has found its way into formal written English in Indian newspapers, which is why we selected it for the first case study based on CORINNE. Section 5 gives the results and a discussion of the case study and Section 6 concludes the paper by foreshadowing potential research avenues using CORINNE as well as the future of the corpus. 


\section{$2 \quad$ Rationale for creating a new corpus of Indian English: CORINNE}

Shortly after he initiated the ICE project, the late Sidney Greenbaum singled out IndE to reflect on "Standard English and the international corpus of English" (Greenbaum 1990). On the one hand, "it is from India that we have the clearest evidence of the internal status of the English spoken by indigenous educated people [...] Among the countries where English is not a native language, India comes closest to a situation in which a new distinctive standard language will emerge" (1990: 81). Such a "standard language, as elsewhere, would tend to be non-regional and represent the consensus of educated speakers", and "one of the applications of descriptive studies [based on the ICE-project] for countries such as India and Nigeria is the promotion of indigenous norms" (1990: 82). ICEIndia was finally launched in 2002 and has since generated a plethora of studies, many of them making a case for the structural nativisation of specific features. However, even though Greenbaum's anticipation of an emerging standard for IndE may match the widespread conviction in the linguistic community that IndE represents a fully-fledged national variety in its own right, the IndE speech community remains unimpressed. There is still no generally accepted standard IndE codified in reference grammars and dictionaries, but many researchers (if not the Indian population at large) associate the variety used in and by supraregional newspapers with an incipient standard. This assumption is at the core of the SAVE (Bernaisch et al. 2011) corpus, which samples 3 million words each from six South Asian varieties of English, represented by two of the leading national newspapers published in English:

The variants of English used in the quality newspapers collected for the SAVE corpus can be seen as representing the most prestigious varieties in the individual linguistic settings, i.e. the kind of language use that is most likely to be codified as soon as such developments are brought under way. (Bernaisch et al. 2011: 1)

Researchers who are interested in profiling acrolectal standard(ising) IndE thus have two corpora at their disposal: the by now slightly dated ICE-India, with all the advantages and disadvantages of a small but carefully balanced corpus, and the more recent, large SAVE-corpus which represents just one register, albeit one that best captures Greenbaum's non-regional consensus of educated speakers. Both ICE and SAVE have comparability as a design feature - comparability across registers as well as varieties around the world in the case of ICE, and comparability across different South Asian varieties in the case of SAVE. 
For L2 varieties of English in general, the structure of the ICE corpora lends itself particularly well to charting the process of nativisation and eventual standardisation. If we take the ICE text category S1A 1-100 (direct conversations) as the equivalent of the least monitored speech (the vernacular in Labov's sense), then we can expect the highest degree of variety-specific innovations in this register. If we find a specific innovative feature in the written language or even in national newspapers, then we are justified in assuming that this feature has become supra-regionally accepted by educated speakers and is thus a likely candidate for inclusion in an emerging standard.

Our aim in compiling CORINNE, a COrpus of Regional INdian Newspaper Englishes (see Section 3 below), is to represent an additional level of language between the local spoken language and the national printed language. We envisage such a corpus project to be useful for several reasons. To begin with, India is a federal state the size of a (sub-)continent, where each regional state is autonomous in selecting its official language. Sridhar highlights the importance of the major regional languages in the Indian linguistic ecology:

They have long, often illustrious, literatures and are media of spirited intellectual and social debate. They are official languages in state administration and legislature, and the medium of instruction at the primary and secondary levels. They are a vibrant presence in print and electronic news and entertainment media. They also command a passionate loyalty of enormous political constituencies. In this respect, these languages are comparable to the major national languages of Europe, such as French, Spanish, Italian, and German. Most of the daytoday communication in India takes place in the regional languages. Linguists estimate that about $90 \%$ of the population speaks one of these languages. (Sridhar 2020: 246)

States such as West Bengal or Maharashtra, though far from being monolingual, have chosen the respective majority language as official language, namely Bangla and Marathi. Some of the linguistically highly diverse north-eastern states have opted for English as their official language. Moreover, literacy rates in general and access to education in English in particular are also unevenly distributed across India, with a state such as Kerala in the South far outperforming other states such as Rajasthan or Gujarat in providing quality education in rural areas (ASER 2018). A corpus of regional newspaper Englishes on its own will not enable us to untangle all the complexities of the use of English embedded in diverse multilingual contexts, but it has the potential to get us closer to more 
local usages. These local usages, by virtue of being admitted to and circulating regionally via the printed medium, represent an interim level within the overall IndE speech community. One research question will thus be whether we can identify features of regional standards in their own right, or whether we are dealing with a repository of variation that awaits koinéisation before moving on to the national level.

Another reason for creating a corpus of Indian newspaper Englishes with a more regional focus is related to the possible motivations for variety-specific features. For all innovations in L2 varieties of English, language contact ranks high as a likely explanation. Contact-induced language change is notoriously difficult to pin down (see Thomason 2010) and even more so in a highly multilingual environment, but there are some uncontroversial cases in IndE: the presentational focus markers only and itself, for instance, are calqued on clitics in Hindi and other Indian languages (Lange 2007). Our corpus of regional newspaper English will be much more sensitive to local varieties of English and thus offer better opportunities for studying contact-induced language change in IndE. Our working hypothesis assumes that the typological diversity of the Indian communicative space will impact local newspaper Englishes to a higher degree than those at the national level. Minimally, we expect to find differences between Englishes in contact with the subcontinent's language families, that is (in descending order of speaker numbers) Indo-Aryan (IA), Dravidian (DR), Austro-Asiatic (AA), and Tibeto-Burman (TB). Whether such differences turn out to be quantitative - in the preference for specific choices over others - or qualitative remains to be investigated. Our case study in Section 4 will address a specific feature of IndE where a contact explanation is tempting, but could so far not be established conclusively on the basis of existing corpora.

\section{Corpus structure and issues of corpus compilation \\ 3.1 Related corpora}

The first two corpora dedicated to Indian varieties of English, the Indian component of the ICE corpora (ICE-India) and the Kolhapur Corpus of Indian English, are both multi-generic. By contrast the more recent corpora SAVE and CORINNE are mono-generic, comprising newspaper texts only. The SAVE corpus was compiled between 2008 and 2011 by Bernaisch, Koch, Mukherjee, and Schilk at Justus Liebig University Giessen and encompasses six distinct South Asian English varieties, each represented by two major English-language newspapers widely circulated and read in the region in question (Bangladesh, India, Maldives, Nepal, Pakistan, and Sri Lanka). Using SAVE and its manual as our 
blueprint, our aim was to complement its IndE component with CORINNE, which covers multiple Indian states and geographical regions and consists of newspapers which are more local in nature.

\subsection{Selection criteria}

As the aim of CORINNE is to cover as many Indian states as possible, any state with a local English-language newspaper was considered eligible for inclusion in the corpus, regardless of the size of its population. At the outset of the corpus compilation project, it was decided that a newspaper chosen to represent a particular state should fulfil the following criteria:

1. It must be based and mainly circulated in the state it is said to represent;

2. It must have a category reporting on local (state/city) news;

3. It must have a print version; however, exceptions can be made if only online newspapers for the state are available;

4. It must be 'scrapable' using our web crawling script (described in Section 3.4);

5. Ideally, it should also contain a non-news articles category, such as editorials, op-eds, letters to the editor, etc.

Criteria 1 and 2 were put in place to help ensure that the subcorpora would better represent the regional aspect of CORINNE. This automatically disqualified such large-scale national publications as The Hindu, The Times of India, Hindustan Times, etc. Criterion 3, according to which newspapers with a print version were favoured, was meant as a way of providing quality control. However, due to the ever-growing importance of the Internet and digital news sources and with that the very realistic feasibility of more and more quality news media existing solely in the digital domain, it was decided that exceptions to this rule could be made. This was relevant when a particular state only had (scrapable) online newspapers to choose from. 'Scrapable' in this context refers to the ability of a website to be downloaded using a computer script. In the case of version 1.0 of CORINNE as of November 2020, however, all of the scraped newspapers had had both a print and an online version. Criterion 4, which concerns the 'scrapability' of each of the newspapers in question, ended up being the biggest limiting factor for what states were able to be represented in the corpus (apart from whether or not they had a local English-language newspaper in the first place), as only very few of the webpages examined had a format that our script was able to work with. See Section 3.5 for a more detailed discussion on the corpus compilation issues we were confronted with during our corpus building process. 
Finally, criterion 5 concerns the content of the items which were to be included in the corpus and is dealt with in more detail in Section 3.3.

\subsection{Origin and content of texts}

Just as with SAVE, news reports and articles make up the foundation of each of the CORINNE subcorpora. The average length of these texts is around 312.63 words. ${ }^{1}$ Only regional, that is, state and/or city news, was of interest to us, which means that national, international, political, etc. news was purposely excluded from the corpus compilation process. This was done mainly to avoid downloading articles containing information sourced from major (national and international) news agencies as, based on our theory, such news items would likely not contain potential examples of regional language use. Another reason to do so was to avoid duplicates across different newspapers. To maintain the focus of the corpus on synchronic variation, it was decided to not regress more than five years in time, which made 2015 the cut-off point for the oldest article we could include. $^{2}$

In a slight modification of the SAVE model, a decision was made to also include 'non-news items' such as editorials, op-eds, featured articles from guest contributors, letters to the editor, etc. in our corpus. These miscellaneous items are longer than news articles on average, with the average text being 1107.62 words in length. ${ }^{3}$ Wherever possible, the aim was to achieve a 2:1 ratio of news articles to non-news items. This criterion was able to be fulfilled for all but the following four subcorpora as of November 2020: Assam, Andhra Pradesh, Tamil Nadu, and Andaman and Nicobar, all of which consist of only news article items. As with the news category, 2015 was set as the cut-off point for the oldest article scraped.

\subsection{Corpus building}

For the data collection portion of the corpus compilation procedure we employed Beautiful Soup, a Python-based web scraping script (Richardson 2007). Due to individual layout and HTML code differences, the script needed to be slightly modified for each of the scraped newspapers. The entirety of the scraping process took place in Jupyter Notebooks, an open-source web application for Python. ${ }^{4}$

For each article, the following metadata was downloaded: URL, headline, date of publication and (when available) the name of the author. Apart from the headlines, which are denoted with $\mathrm{a}<\mathrm{h}></ \mathrm{h}>$ tag, the metadata is not included in the final corpus (except for cases where the date and/or the name of the author are part of the main body of the article), but can be made available on request. 
After the desired articles and their respective metadata had been downloaded, they were divided up into files of around 100,000 to 250,000 words in length. What followed was the random sampling of the files which were to make up each 1.5 million word subcorpus, provided there was enough downloaded material (i.e., around 2 million words or more) to make random sampling worthwhile. Otherwise, the entirety of the article 'population' was used.

The final step involved (mostly manual) data processing and quality control. This part, which varied from newspaper to newspaper, mainly included removal of articles either sourced from news agencies or containing agency inputs, removal of contributions (such as letters to the editor) from non-local authors, removal of duplicates, removal of image captions, as well as addressing minor formatting issues.

A feature that is currently in the pipeline is the addition of a unique ID to each article in the corpus to facilitate quoting and cross-referencing during research and publishing. This feature should be included in CORINNE by the time of its official publication. POS-tagging is also currently in progress.

\subsection{Issues of corpus compilation}

We were confronted with several issues during our corpus compilation process. As previously mentioned, two limiting factors were obvious from the outset, namely that (1) not every state had a regional English-language newspaper, and (2) most of the newspapers under initial consideration were not scrapable using our Beautiful Soup script. The second factor greatly affected what newspapers we were able to include in the finished corpus although it can hopefully be mitigated in the future as our code becomes more sophisticated.

Another difficulty we faced during the corpus building process concerned the uniformity of the content of interest across the different newspapers, in particular the texts from the various 'non-news' categories. No two newspapers happened to be alike in the kind of non-news content they offer, and, as mentioned above, four of the scraped newspapers did not have any usable non-news content. This may pose slight difficulties as far as cross-regional comparability is concerned, for instance due to potential differences in register across the slightly different textual subgenres contained in the non-news components of each subcorpus. Thus, this factor should be kept in mind when conducting comparative research across different CORINNE subcorpora.

Another issue we were confronted with during the scraping portion concerned the quantity of the content that was ultimately able to be downloaded. Perhaps understandably, most of the newspapers we worked with have an online version which is newer and thus not as extensive as their print and/or e-paper 
archives. Thus, although we had originally planned not to regress further than five years in time to keep our data as current as possible, most newspapers only provided us with one or, at most, two years' worth of material. This also means that, unsurprisingly, most articles from the year 2020 are bound to be dominated by news about the novel coronavirus.

\subsection{Overview and word count}

As of November 2020, CORINNE consists of 13 subcorpora, thus representing 13 Indian states and spanning different geographical regions of India (see Figure $1)$ :

- North: Jammu and Kashmir, Uttarakhand

- North East: Arunachal Pradesh, Assam, Meghalaya, Nagaland

- South: Andhra Pradesh, Karnataka, Kerala, Tamil Nadu, Telangana

- West: Goa

- Other: Andaman and Nicobar

All of the current subcorpora apart from the Kerala component are around 1.5 million words in size, which makes CORINNE 19.7 million words in total. ${ }^{5}$ 


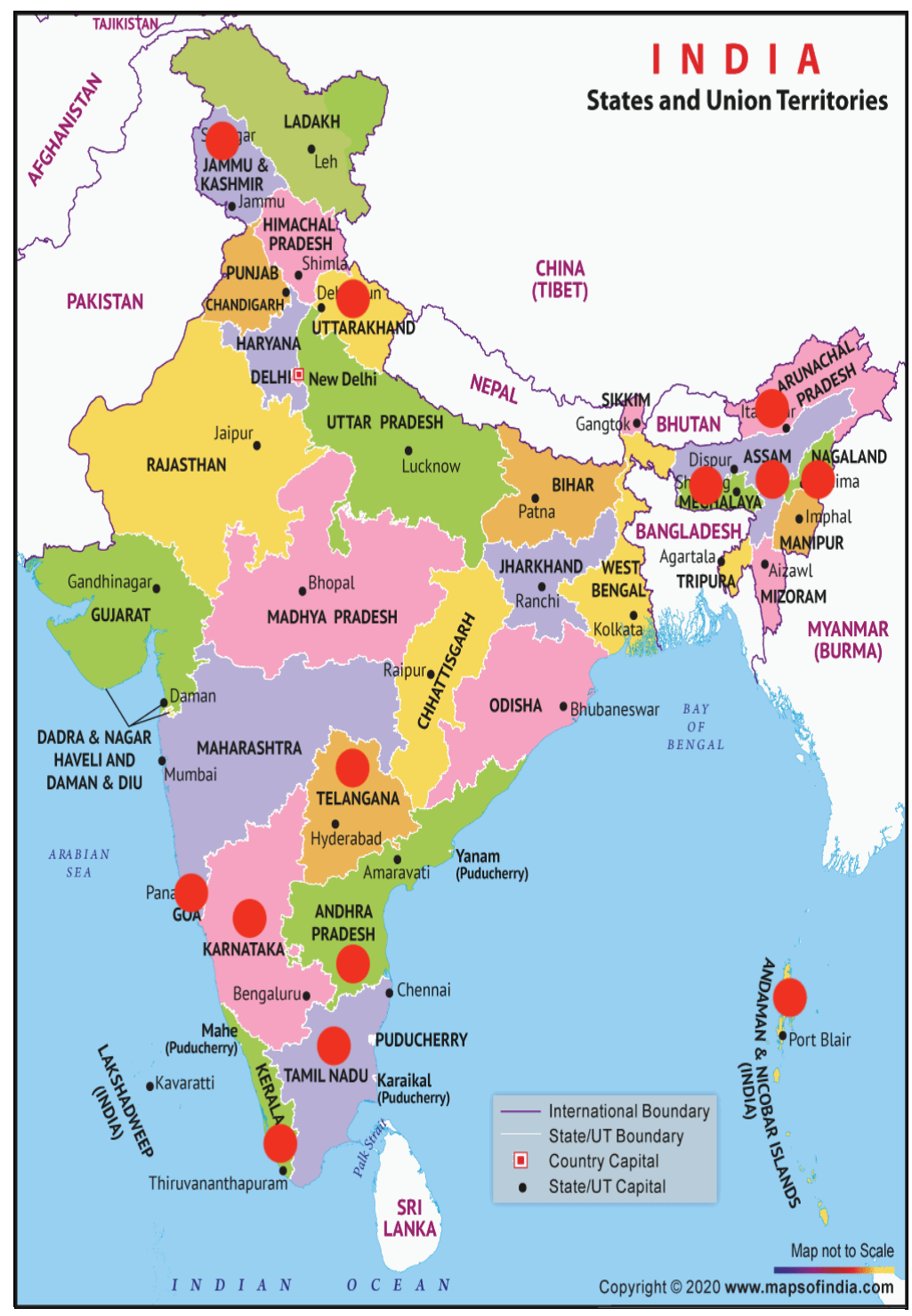

Figure 1: States and regions included in CORINNE as of November 2020 marked with red circles ${ }^{6}$ 
As mentioned above, our ultimate aim with CORINNE is to cover as many states of India as possible. An update to the current subcorpus lineup is in progress, with such states/union territories as Gujarat, Maharashtra, Odisha, Tripura, and NCT Delhi currently being worked on. The newspapers already included in CORINNE as well as background information including the region and state where they are published, the time span and categories included in the corpus, as well as the total word count are presented in Table 1:

Table 1: Overview of the included newspapers and words per newspaper

\begin{tabular}{|c|c|c|c|c|c|}
\hline Region & $\begin{array}{c}\text { State } \\
\text { (+main } \\
\text { languages })^{7}\end{array}$ & Newspaper & $\begin{array}{l}\text { Time } \\
\text { span }\end{array}$ & $\begin{array}{c}\text { Categories } \\
\text { (+words) }\end{array}$ & $\begin{array}{c}\text { Total } \\
\text { words }\end{array}$ \\
\hline UT & $\begin{array}{l}\text { Andaman and } \\
\text { Nicobar } \\
\text { Bengali } 25.71 \% \\
\text { Hindi } 18.23 \% \\
\text { Tamil } 17.68 \%\end{array}$ & $\begin{array}{l}\text { Andaman Sheekha } \\
\text { http://www.andaman- } \\
\text { sheekha.com/ }\end{array}$ & $\begin{array}{l}\text { Feb } 2015- \\
\text { Aug } 2020\end{array}$ & $\begin{array}{l}\text { News } \\
(1,599,277)\end{array}$ & $1,599,277$ \\
\hline North & $\begin{array}{l}\text { Jammu and } \\
\text { Kashmir } \\
\text { Kashmiri } 53.49 \% \\
\text { Dogri } 21.74 \% \\
\text { Hindi } 18.44 \%\end{array}$ & $\begin{array}{l}\text { Kashmir Observer } \\
\text { https://kashmirob- } \\
\text { server.net/ }\end{array}$ & $\begin{array}{l}\text { Sep } 2015- \\
\text { Aug } 2020\end{array}$ & $\begin{array}{l}\text { News } \\
(1,074,181) \\
\text { In Depth } \\
(558,988)\end{array}$ & $1,633,169$ \\
\hline North & $\begin{array}{l}\text { Uttarakhand } \\
\text { Hindi } 87.95 \%\end{array}$ & $\begin{array}{l}\text { Garhwal Post } \\
\text { https://garhwalpost.in/ }\end{array}$ & $\begin{array}{l}\text { May } 2018- \\
\text { Oct } 2020\end{array}$ & $\begin{array}{l}\text { News } \\
(1,064,913) \\
\text { Editorials }+ \\
\text { Features } \\
(442,284)\end{array}$ & $1,507,197$ \\
\hline $\begin{array}{l}\text { North } \\
\text { East }\end{array}$ & $\begin{array}{l}\text { Arunachal } \\
\text { Pradesh } \\
\text { Nissi/Dafla } \\
18.97 \% \\
\text { Adi } 17.61 \% \\
\text { Bengali } 8.85 \%\end{array}$ & $\begin{array}{l}\text { Arunachal Times } \\
\text { https://arunachaltimes.in/ }\end{array}$ & $\begin{array}{l}\text { Sep } 2017- \\
\text { Feb } 2020\end{array}$ & $\begin{array}{l}\text { News } \\
(1,033,899) \\
\text { Editorials } \\
(555,927)\end{array}$ & $1,589,826$ \\
\hline
\end{tabular}




\begin{tabular}{|c|c|c|c|c|c|}
\hline $\begin{array}{l}\text { North } \\
\text { East }\end{array}$ & $\begin{array}{l}\text { Assam } \\
\text { Assamese } \\
48.81 \% \\
\text { Bengali } 27.55 \% \\
\text { Hindi } 5.89 \%\end{array}$ & $\begin{array}{l}\text { Assam Tribune } \\
\text { http://www.assamtri- } \\
\text { bune.com/ }\end{array}$ & $\begin{array}{l}\text { Sep 2014- } \\
\text { August } \\
2019\end{array}$ & $\begin{array}{l}\text { News } \\
(1,514,147)\end{array}$ & $1,514,147$ \\
\hline $\begin{array}{l}\text { North } \\
\text { East }\end{array}$ & $\begin{array}{l}\text { Meghalaya } \\
\text { Khasi } 47.05 \% \\
\text { Garo } 31.41 \% \\
\text { Bengali } 8.01 \%\end{array}$ & $\begin{array}{l}\text { Shillong Times } \\
\text { https://theshillong- } \\
\text { times.com/ }\end{array}$ & $\begin{array}{l}\text { Jun } 2016- \\
\text { Jun } 2020\end{array}$ & $\begin{array}{l}\text { News } \\
(1,175,744) \\
\text { Editorial } \\
(475,281)\end{array}$ & $1,651,025$ \\
\hline $\begin{array}{l}\text { North } \\
\text { East }\end{array}$ & $\begin{array}{l}\text { Nagaland } \\
\text { Ao } 12.94 \% \\
\text { Konyak } \\
12.46 \% \\
\text { Lotha } 8.46 \%\end{array}$ & $\begin{array}{l}\text { Morung Express } \\
\text { https://www.morungex- } \\
\text { press.com/ } \\
\text { Nagaland Post } \\
\text { http://www.nagaland- } \\
\text { post.com/ }\end{array}$ & $\begin{array}{l}\text { Jan } 2014- \\
\text { Mar 2014; } \\
\text { Mar 2019- } \\
\text { Jan } 2019 \\
(\mathrm{ME}) \\
\text { Dec } 2019- \\
\text { Oct } 2020 \\
\text { (NP) }\end{array}$ & $\begin{array}{l}\text { News } \\
(953,545) \\
\text { Editorial }+ \\
\text { Public } \\
\text { Space } \\
(590,857)\end{array}$ & $1,544,402$ \\
\hline South & $\begin{array}{l}\text { Andhra Pradesh } \\
\text { Telugu } 83.85 \% \\
\text { Urdu } 8.63 \% \\
\text { Hindi } 3.23 \%\end{array}$ & $\begin{array}{l}\text { Hans India } \\
\text { https://www.thehansin- } \\
\text { dia.com/ }\end{array}$ & $\begin{array}{l}\text { Jul } 2015- \\
\text { Jan } 2020\end{array}$ & $\begin{array}{l}\text { News } \\
(1,508,659)\end{array}$ & $1,508,659$ \\
\hline South & $\begin{array}{l}\text { Karnataka } \\
\text { Kannada } 65.92 \% \\
\text { Urdu } 10.48 \% \\
\text { Telugu } 7.00 \%\end{array}$ & $\begin{array}{l}\text { Star of Mysore } \\
\text { https://starofmysore.com/ }\end{array}$ & $\begin{array}{l}\text { Feb } 2017- \\
\text { Apr } 2020\end{array}$ & $\begin{array}{l}\text { News } \\
(1,145,767) \\
\text { Editorial } \\
(425,173)\end{array}$ & $1,570,849$ \\
\hline South & $\begin{array}{l}\text { Kerala } \\
\text { Malayalam } \\
96.74 \%\end{array}$ & $\begin{array}{l}\text { Madhyamam } \\
\text { https:// } \\
\text { english.madhyamam.com } \\
\text { / }\end{array}$ & $\begin{array}{l}\text { Jan } 2019- \\
\text { Sep } 2020\end{array}$ & $\begin{array}{l}\text { News } \\
(594,288) \\
\text { Opinion } \\
(438,861)\end{array}$ & $1,033,149$ \\
\hline South & $\begin{array}{l}\text { Tamil Nadu } \\
\text { Tamil } 89.41 \% \\
\text { Telugu } 5.65 \%\end{array}$ & $\begin{array}{l}\text { News Today } \\
\text { https://newstoday- } \\
\text { net.com/ }\end{array}$ & $\begin{array}{l}\text { Aug } 2018- \\
\text { Aug } 2020\end{array}$ & $\begin{array}{l}\text { News } \\
(1,560,311)\end{array}$ & $1,560,311$ \\
\hline
\end{tabular}




\begin{tabular}{|c|c|c|c|c|c|}
\hline South & $\begin{array}{l}\text { Telangana } \\
\text { Telugu } 77 \% \\
\text { Urdu } 12 \%\end{array}$ & $\begin{array}{l}\text { Telangana Today } \\
\text { https://telanganato- } \\
\text { day.com/ }\end{array}$ & $\begin{array}{l}\text { Mar } 2017- \\
\text { Feb } 2020\end{array}$ & $\begin{array}{l}\text { News } \\
(1,072,726) \\
\text { Editorial + } \\
\text { Opinion } \\
(448,854)\end{array}$ & $1,521,580$ \\
\hline West & $\begin{array}{l}\text { Goa } \\
\text { Konkani } 57.13 \% \\
\text { Marathi } 22.57 \% \\
\text { Hindi } 5.7 \%\end{array}$ & $\begin{array}{l}\text { Navhind Times } \\
\text { https://www.navhind- } \\
\text { times.in/ }\end{array}$ & $\begin{array}{l}\text { Jan } 2020- \\
\text { Sep } 2020\end{array}$ & $\begin{array}{l}\text { News } \\
(1,192,077) \\
\text { Opinion } \\
(336,528)\end{array}$ & $1,528,605$ \\
\hline \multicolumn{5}{|r|}{ TOTAL } & $19,762,196$ \\
\hline
\end{tabular}

\section{Case study: 'Intrusive as'}

For our case study, we continue our previous analyses of the 'intrusive as' construction (Koch et al. 2016; Lange 2016) using two subcorpora of CORINNE as our data. After an introduction to the construction, we highlight the potential of analysing 'intrusive $a s$ ' as a contact-induced feature. Then, we summarise key findings from previous studies and introduce the dataset and the method for the case study.

\subsection{The 'intrusive as' construction}

The following joke has a long pedigree. Originally attributed to the Marx Brothers, this version comes from the musical Singin' in the Rain (1952). It is kept alive by teachers trying to explain the difference between a ditransitive and a complex-transitive construction:

Don Lockwood (Gene Kelly): Call me a cab.

Cosmo (Donald O’Connor): Okay, you're a cab.

The joke (if we can still call it that) rests on the structural ambiguity available with call, which can either take two objects $\left(\mathrm{SVO}_{\mathrm{i}} \mathrm{O}_{\mathrm{d}}\right)$ or an object and an object complement $\left(\mathrm{SVOC}_{\mathrm{O}}\right)$ or "predicative complement" in Huddleston's terminology (2002: 53). In complex-transitive constructions, the "predicative complement characteristically denotes a property that is ascribed to the referent of the [...] object" (2002: 53), in the case of our joke the property of being a cab. Verbs occurring in the complex-transitive complementation pattern can be broadly subclassified into 'current' and 'resulting' or 'depictive' and 'resultative'; the 
former labels are applied by Quirk et al. (1985), the latter by Huddleston (2002); these are now the more common terms in the literature on the topic.

Nihalani et al. (1979) have described 'intrusive as' in complex-transitive verb complementation as a feature of IndE. Two examples from the spoken section of ICE-India illustrate the pattern:

(1) Everybody all of us like eating sweets and we develop what you call as $<,>$ a cavity

Is it not? (ICE-IND:S1B-007\#252-3:1:A)

(2) Hindi is uh $<,>$ just now a national language

It doesn't have a identity of its own

So Hindi could also be termed as only a regional literature (ICEIND:S2A-022\#90-92)

Both call and term are current/depictive verbs and fall in Quirk et al.'s subcategory "factual speech act verbs" (1985: 1196). They never occur with as in standard British (or American, for that matter) English, unlike others where as is optional (appoint, consider) or even mandatory (describe as, regard as). This innovative construction with as with complex-transitive verbs such as call, name, declare, term, $d u b$, etc. is neither restricted to the spoken language nor to IndE, but is attested in other South Asian Englishes as well, albeit to different degrees (see Section 4.2 below). One possible explanation for this pattern has been put forward by Sridhar, who notes that:

The use of as with call, consider, etc. is a pervasive characteristic of Dravidian English. This is probably motivated by the fact that, in Dravidian languages, speech material such as technical terms, names, and quotations have to be marked by the quotative particle, a form of [an] 'to say'. (1992: 142)

Subbarao (2012: 203) points out that the use of the quotative in its 'identifier' function is not restricted to the Dravidian languages: "Just as in Sanskrit [...], the quotative is used in naming and labeling in Marathi, Assamese (IA), the Dravidian languages and in some Tibeto-Burman languages". This feature may be illustrated with a small trilingual parallel corpus set in stone: the close-ups below are taken from an inscription at the Pitalkhora caves close to Daulatabad Fort in Aurangabad, Maharashtra, providing information about the historical site in the state's official language Marathi (Figure 2) and India's two official languages Hindi (Figure 3) and English (Figure 4). ${ }^{8}$ 


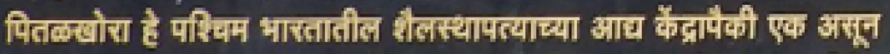

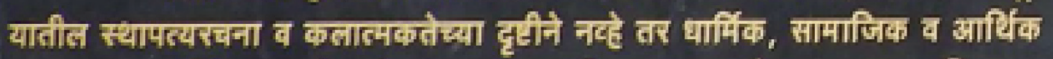

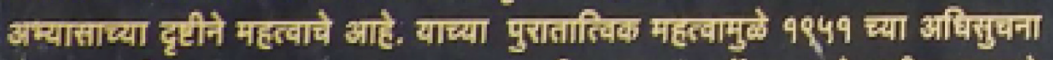

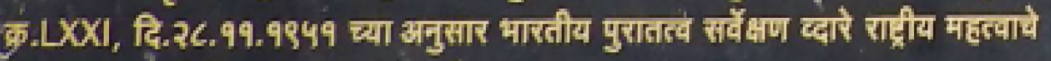
स्मारक म्नुणू घोयित करण्यात आले आहे.

Bितैबर 2094 भारतीय पुरापत्व अर्वैधण, औरंगादाध

Figure 2: Marathi version of the stone inscription at Pitalkhora caves

पितलखोरा पश्चिम भारत में शैलस्थापत्य के आघ्य केंद्रो में से एक था जो केवल स्थापत्य रचना व कलात्मकता की दृसीसे आपेतु धार्मिक, सामाजिक व आर्थिक अध्ययन की दृटी से भी महत्वपूर्ण है। गुंफाओं के पुरातात्विक महत्व को ध्यान में रखते हुए १९५१ की अधिसुचना क्र.LXXI, दि.२८.११.१९५१ के अर्त्तगत भारतीय पुरातत्व सर्वेक्षण व्दारा इसे राप्रीय महत्व के स्मारक के रुप में घोषित किया गया है।

डिसैंबर २०१५

भारतीय पुरातल्व सर्वेक्षण, औरंगाबाद

Figure 3: Hindi version of the stone inscription at Pitalkhora caves

Pitalkhara is one of the earliest centers of rock-cut architecture in the western india remains important in the study of history and art for its architectural wealth and source of epigraphical, religious, social, economic studies as well. Due to its archaeologlcal importance, the Archaeological Survey of India declared it as a monument of national importance vide notification No. LXXI of 1951, dated 28.11.1951.

December, 2015

Archaeological Survey of India

Aurangabad Circle

Figure 4: English version of the stone inscription at Pitalkhora caves 
What is of interest here is the line containing intrusive as: “... the Archaeological Survey of India declared it as a monument of national importance..." The Marathi version includes the quotative particle mhanun, the Hindi version uses an altogether different construction. ${ }^{9}$ It is thus tempting to assume that intrusive as in the English translation '... declared as...' is calqued on the Marathi particle mhanun:

Marathi:

$\begin{array}{llll}\text { bharatiya puratatva sarvekshan } & \text { dware } & \text { rashtriya mahatvache smarak mhanun } \\ \text { Indian Archeological Survey } & \text { by } & \text { national importance monument } & \text { (quotative particle) } \\ \text { ghoshit karnyat ale ahe } & & \\ \text { declare-do-be 3SG PRS PRF } & & \end{array}$

'The Archeological Survey of India has declared it as a monument of national importance.'

Hindi:

$\begin{array}{llll}\text { bharatiya puratatva sarvekshan } & \text { dwara } & \text { ise } & \text { rashtriya mahatvake smarak } \\ \text { Indian Archeological Survey } & \text { by } & \text { it } & \text { national importance monument } \\ \text { ke roop mein } & \text { ghoshit kiya gaya-hai }\end{array}$
$\begin{array}{ll}\text { of - form - in } & \text { declare-do-be 3SG PRS PRF }\end{array}$

'The Archeological Survey of India has declared it in the form of a monument of national importance.'

Even though the classical Indo-Aryan language Sanskrit already had a quotative particle for naming and labelling (Hock 1982), its occurrence in modern IA languages such as Marathi is generally considered to be derived from contact with the Dravidian languages (Subbarao et al. 1989: 90). Table 2 summarises the available information about the presence or absence of a quotative with the specific function of 'identifier' in Indian languages. This table relies largely on the very specific publications on the topic; its extension to further languages would require extensive fieldwork, as most reference grammars remain inconclusive on such a subtle point. This is especially true for the Tibeto-Burman languages, which combine a high number of separate languages with low speaker numbers: 66 scheduled and non-scheduled TB languages are spoken by 1.01 per cent of 
the overall Indian population according to the 2011 Census. The default assumption for those IA languages not listed in the table, however, would be that they do not have a quotative used as identifier, since "only the Outer Group of IndoAryan languages" (Subbarao et al. 1989: 92) have borrowed this feature from Dravidian.

Table 2: South Asian languages in which the quotative particle also has the function of 'identifier' (i.e., occurs with verbs of naming and labelling)

\begin{tabular}{|l|l|l|l|l|}
\hline Language & Family & Status & Source & identifier \\
\hline Adi & TB & NSL & Saxena 1988: 381 & ++ \\
\hline Assamese & IA & SL & Subbarao et al. 1989: 97 & ++ \\
\hline Bengali & IA & SL & Kachru 1979: 67 & -- \\
\hline Hindi/Urdu & IA & SL & Kachru 1979: 76 & -- \\
\hline Kannada & DR & SL & Sridhar 1990: 163; Kachru 1979: 73 & ++ \\
\hline Malayalam & DR & SL & Subbarao 2012: 203 & ++ \\
\hline Manipuri & TB & SL & Patnaik 1998: 82; Saxena 1988: 381 & ++ \\
\hline Marathi & IA & SL & Pandharipande 1997: 6, 299; Subbarao 2012: 204 & ++ \\
\hline Nepali & IA & SL & Kachru 1979: 70 & -- \\
\hline Oriya/Odia & IA & SL & Kachru 1979: 71 & ++ \\
\hline Punjabi & IA & SL & Bhatia 2013: 3, 176 & -- \\
\hline Sanskrit & IA & SL & Kachru 1979: 65; Hock 1982 & ++ \\
\hline Tamil & DR & SL & Kachru 1979: 74; Subbarao et al. 1989: 97 & ++ \\
\hline Telugu & DR & SL & Subbarao 2012: 204 & ++ \\
\hline
\end{tabular}

The abbreviations in the second column denote the language families: IA Indo-Aryan, DR - Dravidian, TB - Tibeto-Burman. ${ }^{10}$ The third column represents each language's status: The Indian constitution recognizes 22 scheduled languages (SL) and 99 non-scheduled languages (NSL). Scheduled languages may receive official support from the respective regional governments and are often the official language of a federal state, with many of these languages having their own script and a long literary tradition. Adi, the only non-scheduled language in the table, is spoken by 248,834 members of the indigenous Adi community (Census of India 2011) who mostly live in the northeastern state Arunachal Pradesh. The language is listed as 'vulnerable' by the UNESCO Interactive Atlas of the World's Languages in Danger. ${ }^{11}$ 
CORINNE is an ideal resource to test the hunch that 'intrusive $a s$ ' in IndE is contact-induced, by pitting one newspaper subcorpus from the Hindi belt against one derived from a southern state with a Dravidian substrate language.

\subsection{Previous findings and motivation}

Studies by Koch et al. (2016) and Lange (2016) consider 'intrusive as' in different corpora and contexts. As the first major publication on the subject, Lange (2016) focussed on the construction in spoken and written IndE using the ICEIndia corpus as well as the SAVE corpus. The corpus data support the conclusion that 'intrusive as' belongs to the repertoire of South Asian Englishes, but its frequency is highly sensitive to medium, register, lemma, and national variety. The data in Table 3 below, with a focus on call (as) and term (as) in IndE, capture the main trends: for call as, there is a sharp decline in usage from the informal to the formal end of the continuum of registers. The low figure of 1.38 per cent for call as in the SAVE corpus indicates that 'intrusive as' with call is not acceptable in newspapers with national coverage. Term as, on the other hand, shows a more or less stable incidence across medium and register and has become the default option in standard(ising) IndE.

Koch et al. (2016) widen the scope by comparing 'intrusive as' in South Asian Englishes and Learner Englishes. The data on South Asian Englishes come from SAVE, while learner data are taken from the International Corpus of Learner English (ICLE; Granger et al. 2009) and the International Corpus Network of Asian Learners of English (ICNALE; Ishikawa 2011). The study shows differences in the frequency of 'intrusive as' between Learner Englishes and second-language varieties as well as a differential distribution of complex-transitive verbs that link the direct object and its complement with as. However, beyond variety- and verb-specific distributional patterns, processing and syntactic variables have an impact on the usage of 'intrusive as'. Based on a statistical analysis using conditional inference trees, Koch et al. (2016: 172) note that "[h] eavy NPs and/or a considerable distance between the verb and its complement definitely favour the occurrence of 'intrusive $a s$ ". This can be explained by the concept of 'redundancy' (Schneider 2012: 65), or, in Rohdenburg's (1996) terminology, 'explicitness': Speakers closer to the English as a Second Language (ESL) and English as a Foreign Language (EFL) points of the cline tend to overtly and, at times, doubly mark categories when there is potential for misunderstandings. Realising 'intrusive $a s$ ' in sentences with a long distance between verb and object complement is, consequently, a way to overtly mark the complement and to ease processing for the hearer. 
The motivation for a new case study of 'intrusive as' lies in the new possibilities of the corpus described in Section 2 of this paper. SAVE allowed the comparison of South Asian varieties of English, while CORINNE allows the direct comparison of written Englishes from different parts of India. Accordingly, we can zoom in on aspects such as the typology of regional languages as well as the entrenchment of English in local communities and, therefore, contribute to a deeper understanding of the fact that there are 'Indian Englishes' as opposed to one 'Indian English'.

Our case study will focus exclusively on call (as) and term (as). The semiautomatic search for verbs allowing the 'intrusive $a s$ ' construction in the 18 million word SAVE-corpus (Koch et al. 2016: 160) did not yield more than the usual suspects in any higher frequency: only $d u b$ could be added to the list comprising call, declare, deem, name, and term. The evidence from Koch et al. (2016) and Lange (2016), summarised in Table 3, shows that call (as) is overall the most frequent verb used in complex-transitive constructions, albeit with only a handful of tokens with 'as' in written IndE. Its mirror image is term (as), which is much rarer generally, but is then predominantly used with as.

Table 3: Overview of call / call as and term / term as in the spoken and written parts of ICE-India and SAVE-India

\begin{tabular}{|c|c|c|c|}
\hline Corpus & ICE-IND spoken & ICE-IND written & SAVE-India \\
\hline $\begin{array}{l}\text { call / call as: } \\
\text { absolute frequencies } \\
\text { frequencies pmw } \\
\text { relative frequency of } \mathrm{V}+a s\end{array}$ & $\begin{array}{l}423 \text { vs. } 95 \\
616.7 \text { vs. } 138.5 \\
18.33 \%\end{array}$ & $\begin{array}{l}136 \text { vs. } 16 \\
312.5 \text { vs. } 36.8 \\
10.52 \%\end{array}$ & $\begin{array}{l}639 \text { vs. } 9 \\
207.3 \text { vs. } 2.9 \\
1.38 \%\end{array}$ \\
\hline $\begin{array}{l}\text { term / term as: } \\
\text { absolute frequencies } \\
\text { frequencies pmw } \\
\text { relative frequency of } \mathrm{V}+\text { as }\end{array}$ & $\begin{array}{l}2 \text { vs. } 16 \\
2.9 \text { vs. } 23.3 \\
88.88 \%\end{array}$ & $\begin{array}{l}2 \text { vs. } 5 \\
4.6 \text { vs. } 11.5 \\
71.42 \%\end{array}$ & $\begin{array}{l}38 \text { vs. } 99 \\
12.3 \text { vs. } 32.1 \\
72.26 \%\end{array}$ \\
\hline
\end{tabular}

[Table based on data from Koch et al. 2016: 163 and Lange 2016: 141, 142: absolute frequencies, frequencies pmw, relative frequencies of call/term vs. call/ term as.]

\subsection{Case study: Data and method}

For our case study, we analysed a sub-section of the CORINNE corpus containing newspapers from Tamil Nadu and Uttarakhand. As Tables 1 and 2 above indicated, Tamil is the majority language of Tamil Nadu and features a quotative for naming and labelling, whereas the majority language of Uttarakhand is 
Hindi, which does not have a comparable quotative marker. The word count as well as the names of the newspapers included in the two subcorpora are shown in Table 4:

Table 4: Subcorpora for the case study on 'intrusive as'

\begin{tabular}{|l|l|l|}
\hline State & Newspaper & Word Count \\
\hline Tamil Nadu & News Today & $1,560,311$ \\
\hline Uttarakhand & Garhwal Post & $1,507,197$ \\
\hline
\end{tabular}

We searched for tokens of call and term in AntConc (Anthony 2019) by looking for all possible word-forms and manually checking the tokens for their relevance in a first step. Tokens were deemed relevant when they occurred as verbs and were used complex-transitively.

After identifying all relevant tokens, we counted the frequency of 'regular' complex-transitive uses of call and term as well as uses with 'intrusive as' in order to be able to compare their frequencies in CORINNE with those found in ICE and SAVE. Since we only consider two verbs in the case study, lemma was deemed irrelevant. We also did not annotate further variables other than voice, since the case study is mostly exploratory and centred on a typological argument.

\section{$5 \quad$ 'Intrusive as' in the CORINNE corpus}

\subsection{Results}

Overall, the procedure described in Section 4 yielded 279 tokens of call/call as in CN-Tamil Nadu and 193 tokens of call/call as in CN-Uttarakhand. For term/ term as, we found 40 tokens in CN-Tamil Nadu and 27 tokens in CN-Uttarakhand. The absolute, normalised (per million words, pmw), and relative frequencies are indicated in Table 5. For the relative frequency, we only give the percentage of how many tokens feature 'intrusive $a s$ '. 
Table 5: Absolute, relative, and normalised frequency per million words (pmw) of 'intrusive as' (INTRAS) with call and term in the CORINNE $(=\mathrm{CN})$ subcorpora for Tamil Nadu and Uttarakhand

\begin{tabular}{|l|l|l|}
\hline Corpus & CN-Tamil Nadu & CN-Uttarakhand \\
\hline & call / call as & \multicolumn{2}{|l|}{} \\
\hline absolute frequency & 244 vs. 35 & 188 vs. 5 \\
\hline normalised frequency pmw & 156.38 vs. 22.43 & 124.73 vs. 3.32 \\
\hline $\begin{array}{l}\text { relative frequency of } \\
\text { INTRAS }\end{array}$ & $12.5 \%$ & $2.6 \%$ \\
\hline & term / term as & \\
\hline absolute frequency & 10 vs. 30 & 13 vs. 14 \\
\hline normalised frequency pmw & 6.41 vs. 19.32 & 8.63 vs. 9.29 \\
\hline $\begin{array}{l}\text { relative frequency of } \\
\text { INTRAS }\end{array}$ & $75.0 \%$ & $51.9 \%$ \\
\hline
\end{tabular}

Applying a chi-squared test $(\alpha=.05)$ to the dataset shows that the frequency differences are statistically significant for call/call as $\left(\chi^{2}=14.57, p=.000135\right)$ but not quite for term/term as $\left(\chi^{2}=3.83, p=.050303\right)$. The distribution of call and call as is similar in SAVE-India (1.38\%) and CN-Uttarakhand (2.6\%), whereas the relative frequency of call as is much higher in $\mathrm{CN}$-Tamil Nadu at 12.5 per cent. Term as is much more frequent in CN-Tamil Nadu, where it occurs at 75.0 per cent compared to 51.9 per cent in $\mathrm{CN}-\mathrm{Uttarakhand}$. The high frequency in $\mathrm{CN}-\mathrm{Tamil}$ Nadu is similar to the frequencies found in both the spoken and written components of ICE-India as well as SAVE, but 51.9 per cent in CN-Uttarakhand is the lowest percentage of term as across all datasets. This outlier goes against the established national trend towards term as as default option; it would be highly instructive to compare this result to other $\mathrm{CN}$-subcorpora covering the Hindi belt.

Both call as and term as are predominantly used for naming and labelling in the two subcorpora, as can be seen in examples (3) and (4):

(3) "I would like to call the art as free flow" NT_Chennai_01.txt

(4) "DMK president M K Stalin termed it as a Tamil betrayal" NT_Tamilnadu_03.txt 
An interesting aspect regarding the grammar of 'intrusive as' concerns the preferred tense and voice with which it is used in the two subcorpora. Term as stands out in this regard since it is used almost exclusively in the past in active voice (example 5) or as a past participle in passives (example 6) in CN-Tamil Nadu and CN-Uttarakhand - only one infinitival use and one token of present tense term as could be found in the former subcorpus and none in the latter.

(5) "in leather and footwear sectors, the Minister termed it as a transparent package"

NT_Chennai_10.txt

(6) "So how come that they were termed as perpetrators"

NT_Chennai_09.txt

Although call as is also preferably used as called as in active or passive contexts in both subcorpora, the distribution is less extreme.

\subsection{Discussion}

The typological overview in Section 4.1 has shown that the languages in contact with English likely have an impact on the presence or absence of the 'intrusive $a s$ ' construction. The figures presented in the results section also suggest that a contact hypothesis is attractive: Tamil as the majority language in Tamil Nadu has a quotative which we argue might be partially responsible for occurrences of 'intrusive $a s$ '. In Uttarakhand's majority language Hindi, no comparable quotative is present - and the figures are, as we would expect, lower.

However, the situation is certainly not that simple. An aspect worth noting again is that the influence of language contact is notoriously elusive, which is why a holistic picture of how a linguistic feature emerges is important. In an innovative approach to language change (in particular in the context of world Englishes), Schneider (2020) comments on the development of 'intrusive $a s^{\prime}$ ' in South Asian Englishes in a framework that views Englishes as Complex Dynamic Systems. According to him, "the spread of call/term as works towards establishing a more systematic and transparent form-meaning mapping, and thus introduces a pocket of order in a complex (and possibly chaotic) subsystem" (2020: 38).

For the data in our CORINNE subcorpora, the presence of a quotative might function as a catalyst that ultimately accelerates a change that is already in motion. This line of reasoning goes together well with the question of how actuation and propagation affect the spread of 'intrusive as' (Koch et al. 2016: 172). Linguistic creativity and interactional needs presumably have, at some point, 
resulted in South Asian speakers using the 'intrusive as' construction in English, most likely calquing it on the quotative of a contact language. 'Interactional needs' refer to the strategies of explicitness and redundancy mentioned above. Creatively and effectively making use of the features available to speakers in their entire linguistic repertoire has long been noted as a crucial aspect in the emergence of innovative features in world Englishes. Another factor that might have an impact on the frequency of 'intrusive $a s$ ' is the presence of analogous constructions in English, such as declare as and regard as.

Since its inception, 'intrusive as' appears to have spread further and is still doing so, with a spread that is likely accelerated in those regions where a similar construction in speakers' mother tongues is prevalent. Like any other linguistic feature, it is affected by frequency effects, and more usage leads to even more usage (cf. Bybee and Thompson 2007; Pfänder et al. 2013). As Schneider (2020) points out, such processes are accompanied by a certain degree of chaos and, hence, unpredictability that can probably only be observed in hindsight.

\section{Conclusion}

This paper set out to introduce CORINNE, the new Corpus of Regional Indian Newspaper Englishes, by describing its development and presenting a case study of 'intrusive as' using a subcorpus of newspapers published in Tamil Nadu and Uttarakhand. The corpus seeks to fill the gap of a corpus that makes comparisons between regionally different Englishes in India possible. In doing so, it helps acknowledge the multifaceted nature of how English is entrenched and used in the Indian states and regions.

Our case study built on previous work by Koch et al. (2016) and Lange (2016) and showed that language contact is a likely factor affecting the frequency of 'intrusive $a s$ '. The calque of 'intrusive $a s$ ' on a quotative in, for instance, Tamil, might be both a factor in the actuation and propagation of the feature. Thus, combining Schneider's (2020) idea of Englishes as Complex Dynamic Systems with a contact hypothesis as well as sociolinguistic concepts appears fruitful for the explanation of the emergence, the development, and the spread of 'intrusive $a s$ ' both across regional Indian Englishes and across verbs.

For future studies, linguists will be able to make use of CORINNE's potential for tapping into regionally different Indian Englishes. As a corpus that contains rather formal written English, lexical as well as morphosyntactic comparisons across newspapers will be most promising. Although the corpus is primarily designed as a tool for linguists, socio-political analyses of topics discussed in the newspapers are also possible. ${ }^{12}$ 


\section{Acknowledgments}

We would like to thank the editors Merja Kytö and Anna-Brita Stenström and an anymous reviewer for their helpful comments on an earlier version of this paper. All remaining shortcomings are entirely our own.

\section{Notes}

1. Value calculated using three randomly selected corpus files from the news category.

2. 2014 was the cut-off point for Assam Tribune and the Morung Express component of the Nagaland subcorpus, the work on which had started in late 2019.

3. Value calculated using three randomly selected corpus files from the nonnews category.

4. We would like to thank Prof. Sergey Yurchenko for his kind assistance in coding the script.

5. The Kerala subcorpus currently contains 1 million words, but we plan on expanding it as more articles become available in the online version of the Madhyamam newspaper.

6. Source: https://commons.wikimedia.org/wiki/File:Map-of-india-politicalenlarge-view.gif, available under the Creative Commons CC0 1.0 Universal Public Domain Dedication.

7. Sources: $52^{\text {nd }}$ Report of the Commissioner for Linguistic Minorities in India (2016) and Report of the Committee for Consultations on the Situation in Andhra Pradesh (2010) for the Telangana data.

8. All three photos were taken by one of the authors.

9. We gratefully acknowledge Kranti Doibale's translations of the Marathi and Hindi versions.

10. More information about the number of languages and speakers for each language family can be found in the relevant section of the Census of India 2011: https://censusindia.gov.in/2011Census/Language_MTs.html.

11. See http://www.unesco.org/languages-atlas/index.php.

12. Anyone interested in accessing CORINNE should contact the team at corinne@tu-dresden.de for further information. 


\section{References}

Anthony, Laurence. 2019. AntConc (Version 3.5.8) [Computer Software]. Tokyo, Japan: Waseda University. Available from https://www.laurenceanthony.net/software.

ASER 2018. Annual State of Education Report. http://www.asercentre.org/

Bashir, Elena. 1996. Mosaic of tongues: Quotatives and complementizers in Northwest Indo-Aryan, Burushaski and Balti. In W. L. Hanaway and W. Heston (eds.). Studies in Pakistani popular culture, 187-286. Lahore: Sange-Meel, with Lok Virsa.

Bernaisch, Tobias, Christopher Koch, Marco Schilk and Joybrato Mukherjee. 2011. Manual to the South Asian Varieties of English (SAVE) Corpus. Giessen: Justus Liebig University, Department of English.

Bhatia, Tej. 2013. Punjabi: A cognitive-descriptive grammar. London: Routledge.

Buschfeld, Sarah and Alexander Kautzsch. 2017. Towards an integrated approach to postcolonial and non-postcolonial Englishes. World Englishes 36(1): 104-126.

Bybee, Joan and Sandra Thompson. 2007. Three frequency effects in syntax. In J. Bybee (ed.). Frequency of use and the organization of language, 269278. Oxford: Oxford University Press.

Census of India. 2011. Data on Language and Mother Tongue. https://censusindia.gov.in/2011Census/Language_MTs.html

Government of India - Ministry of Minority Affairs. 2016. 52 $2^{\text {nd }}$ Report of the Commissioner for Linguistic Minorities (July 2014 to June 2015). http:// www.minorityaffairs.gov.in/sites/default/files/

2.\%2052nd\%20Report\%20English.pdf

Government of India - Press Information Bureau. 2010. Report of the Committee for Consultations on the Situation in Andhra Pradesh. https:// archive.pib.gov.in/archieve/others/2011/jan/d2011010502.pdf

Granger, Sylviane, Estelle Dagneaux, Fanny Meunier and Magali Paquot (eds.). 2009. International Corpus of Learner English. Version 2 (Handbook + CD-Rom). Louvain-la-Neuve: Presses universitaires de Louvain.

Greenbaum, Sidney. 1990. Standard English and the International Corpus of English. World Englishes 9: 79-83.

Hock, Hans Henrich. 1982. The Sanskrit quotative: A historical and comparative study. Studies in the Linguistic Sciences 12(2): 39-85. 
Huddleston, Rodney. 2002. Syntactic overview. In R. Huddleston and G. K. Pullum (eds.). The Cambridge grammar of the English language, 43-70. Cambridge: Cambridge University Press.

Ishikawa, Shin'ichiro. 2011. A new horizon in learner corpus studies: The aim of the ICNALE project. In G. R. S. Weir, S. Ishikawa and K. Poonpon (eds.). Corpora and language technologies in teaching, learning and research, 3-11. Glasgow: University of Strathclyde Publishing.

Kachru, Yamuna. 1979. The quotative in South Asian languages. South Asian Languages Analysis 1: 63-77.

Koch, Christopher, Claudia Lange and Sven Leuckert. 2016. This hair-style called as 'duck tail' - the 'intrusive as'-construction in South Asian varieties of English and learner Englishes. International Journal of Learner Corpus Research 2(2): 151-176.

Labade, Sachin, Claudia Lange and Sven Leuckert. 2020. English in India: Global aspirations, local identities at the grassroots. In S. Buschfeld and A. Kautzsch (eds.). Modelling World Englishes: A joint approach to postcolonial and non-postcolonial varieties, 85-111. Edinburgh: Edinburgh University Press.

Lange, Claudia. 2007. Focus marking in Indian English. English World-Wide 28(1): 89-118.

Lange, Claudia. 2016. The 'intrusive as' construction in South Asian varieties of English. World Englishes 35(1): 133-146.

Nihalani, Paroo, R. K. Tongue and Priya Hosali. 1979. Indian and British English: A handbook of usage and pronunciation. New Delhi: Oxford University Press.

Pandharipande, Rajeshwari. 1997. Marathi. London: Routledge.

Patnaik, Manideepa. 1998. Quotatives revisited. South Asian Language Review 8(2): 79-96.

Pfänder, Stefan, Heike Behrens, Peter Auer, Daniel Jacob, Rolf Kailuweit, Lars Konieczny, Bernd Kortmann, Christian Mair and Gerhard Strube. 2013. Erfahrung zählt. Frequenzeffekte in der Sprache - ein Werkstattbericht. Zeitschrift für Literaturwissenschaft und Linguistik 43: 7-32.

Quirk, Randolph, Sidney Greenbaum, Geoffrey Leech and Jan Svartvik. 1985. A comprehensive grammar of the English language. London: Longman.

Richardson, Leonard. 2007. Beautiful Soup documentation. https://www.crummy.com/software/BeautifulSoup/bs4/doc/ 
Rohdenburg, Günter. 1996. Cognitive complexity and increased grammatical explicitness in English. Cognitive Linguistics 7(2): 149-182.

Saxena, Anju. 1988. On syntactic convergence: The case of the verb say in Tibeto-Burman. In S. Axmaker, A. Jaisser and H. Singmaster (eds.). General session and parasession on grammaticalization, 375-388. Berkeley: Berkeley Linguistic Society.

Schneider, Edgar W. 2012. Exploring the interface between World Englishes and second language acquisition - and implications for English as a lingua franca. Journal of English as a Lingua Franca 1(1): 57-91.

Schneider, Edgar W. 2020. Calling Englishes as Complex Dynamic Systems: Diffusion and restructuring. In A. Mauranen and S. Vetchinnikova (eds.). Language change. The impact of English as a lingua franca 15-43. Cambridge: Cambridge University Press.

Sridhar, S. N. 1992. The ecology of bilingual competence: Language interaction in indigenized varieties of English. World Englishes 11(2-3): 141-150.

Sridhar, S. N. 2020. Indian English. In K. Bolton, W. Botha and A. Kirkpatrick (eds.). The handbook of Asian Englishes, 241-277. Hoboken, NJ: WileyBlackwell.

Subbarao, Karumuri V. 2012. South Asian languages: A syntactic typology. Cambridge: Cambridge University Press.

Subbarao, Karumuri V., C. Visvanath Rao, Anju Saxena and Nalini Rau. 1989. The verb 'say' in South Asian languages: A study in linguistic convergence. In A. Mukherjee (ed.). Language change and language variation, 89-104. Hyderabad: Centre of Advanced Study, Osmania University.

Thomason, Sarah. 2010. Contact explanations in linguistics. In R. Hickey (ed.). The handbook of language contact, 29-47. Oxford: Wiley-Blackwell. 